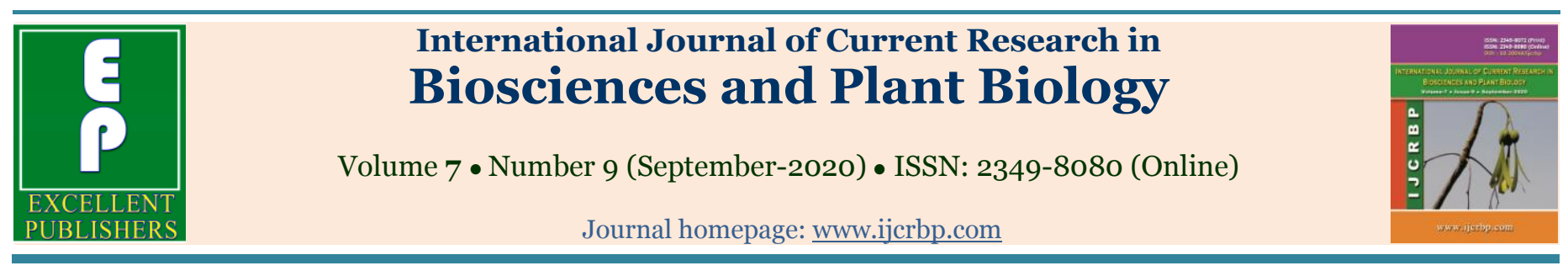

\title{
Effectiveness of organic culture media combination on propagation of Gigaspora sp. indigenous to Sorowako, Indonesia
}

\author{
Muhammad Akhsan Akib ${ }^{1 *}$, Andi Nuddin'1 and Retno Prayudyaningsih² \\ ${ }^{1}$ Universitas Muhammadiyah Parepare. South Sulawesi, 91131. Indonesia \\ ${ }^{2}$ Environment and Forestry Research and Development Institute of Makassar, South \\ Sulawesi, 90243, Indonesia \\ *Corresponding author; e-mail: akhsanbagus@umpar.ac.id
}

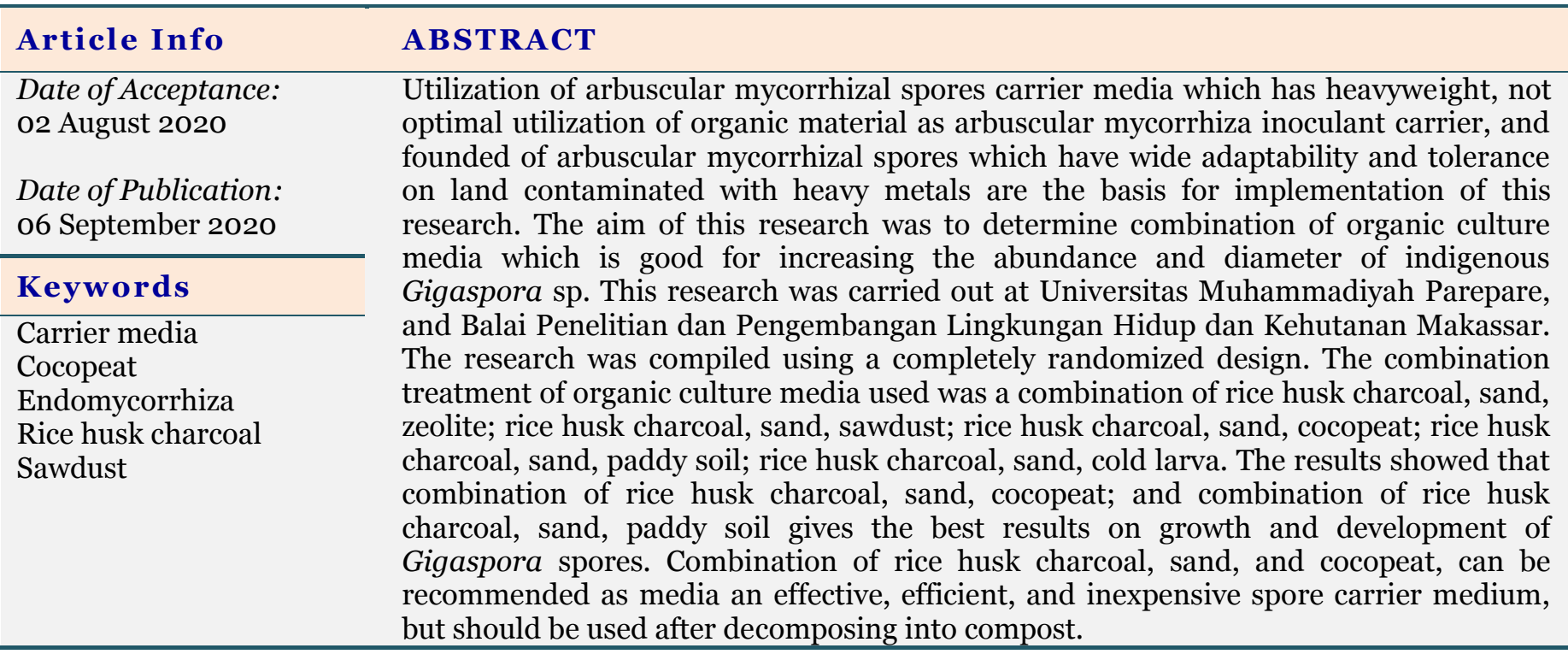

\section{Introduction}

Mycorrhizae are mutually symbiotic relationship between soil fungi and plant roots (Bender et al., 2014). These fungi are important microorganisms for plants because arbuscular mycorrhizae (AM) play a role in supporting plant growth through increased absorption of plant nutrients, resistance, and tolerance of plants to abiotic and biotic stress (Begum et al., 2019). Therefore, AM needs to be developed as a biological agent. The abundance of indigenous mycorrhizal spores in the post-mining area of Sorowako was found in Acaulospora sp., 70.1\%, Gigaspora sp., 22.2\%, and Glomus sp., 7.1\% (Akib et al., 2018). These indigenous mycorrhizae have been identified and have a high tolerance level for heavy metal concentrations.

One obstacle to the lack of use of AM technology in the mining, forestry, plantation, and agricultural industries is the limited availability of AM inoculants that are commercially produced on a 
large scale (Coelho et al., 2014; Cely et al., 2016), even though the production of AM inoculants is relatively simple. The most important thing in the $\mathrm{AM}$ production process is the availability of human resources, good quality starter inoculums, host plants, production facilities, and carrier materials (Coelho et al., 2014; Mukhongo et al., 2016).

Carrier materials that are often used as culture media are generally soil, sand, expanded clay, peat, and zeolite (Malusa et al., 2012; Kokkoris et al., 2019), but these media have obstacles if large amounts of mobilization are carried out because they have heavyweights.

The use of organic materials as carriers of AM inoculants has not been widely used. Several research results show that $\mathrm{AM}$ has positive interactions with organic matter in the soil, including soil contaminated with heavy metals, saline soil, and soil that is hit by drought (Medina et al., 2010; Asmelash et al., 2016; Begum et al., 2019). Therefore, it is hoped that the availability of light, porous, homogeneous, inexpensive, and easy to obtain carrier media is the aim of this research.

\section{Materials and Methods}

This research was conducted at the Agrotechnology Laboratory of the Faculty of Agriculture, Animal Husbandry and Fisheries, Universitas Muhammadiyah Parepare $\left(3^{\mathrm{O}} 59^{\prime} \mathrm{S} 119^{\mathrm{O}} 39^{\prime} \mathrm{E}\right)$, and the Microbiology Laboratory, Balai Penelitian dan Pengembangan Lingkungan Hidup dan Kehutanan Makassar $\left(5^{\circ} \mathrm{O} 5^{\prime} \mathrm{S} 119^{\circ} 3 \mathrm{O}^{\prime} \mathrm{E}\right)$. This study used a completely randomized design with three treatments of organic culture media combination (Fig. 1), namely; rice husk charcoal, sand, zeolite
(KM1, as control); rice husk charcoal, sand, sawdust (KM2); rice husk charcoal, sand, cocopeat (KM3); rice husk charcoal, sand, paddy soil (KM4), rice husk charcoal, sand, cold magma (KM5), with a ratio of 1: 1: 1 . The culture media combination was first homogenized and sterilized, before being put into a culture media pot as much as $1000 \mathrm{~cm} 3$. Analysis of the chemical and physical properties of media was carried out in the soil science laboratory, Faculty of Agriculture, Hasanuddin University, Makassar.

The inoculant of AM Gigaspora sp. indigenous Sorowako used was pure culture propagule from previous research. Every $50 \mathrm{~g}$ of propagule contains 25-30 spores. The composite corn seeds (Zea mays L) to be used as a host plant are first soaked in a disinfectant solution for 5-10 minutes with a concentration of $2 \%$ as an attempt to sterilize the surface, then the seeds are dried to air. Planting was carried out in a culture pot containing a combination of media, the host plant seeds were planted together with the provision of propagule AM Gigaspora sp. Plants are maintained until the age of 60 days, then trapping for 30 days.

The spores of AM Gigaspora sp were isolated from every $50 \mathrm{~g}$ of combination media using the wet filtering method, and the sucrose gradient centrifugation method (Walker et al., 1982). The calculation of number and measurement of the spore diameter was carried out using an electron microscope at a magnification of 40 times. The observed data from the calculation of the number and diameter of AM Gigaspora spores were analyzed using analysis of variance (ANOVA), and the Duncan test was carried out at $\mathrm{P}=0.05$ if there was a significant influence by treatment factors (Akib, 2019).
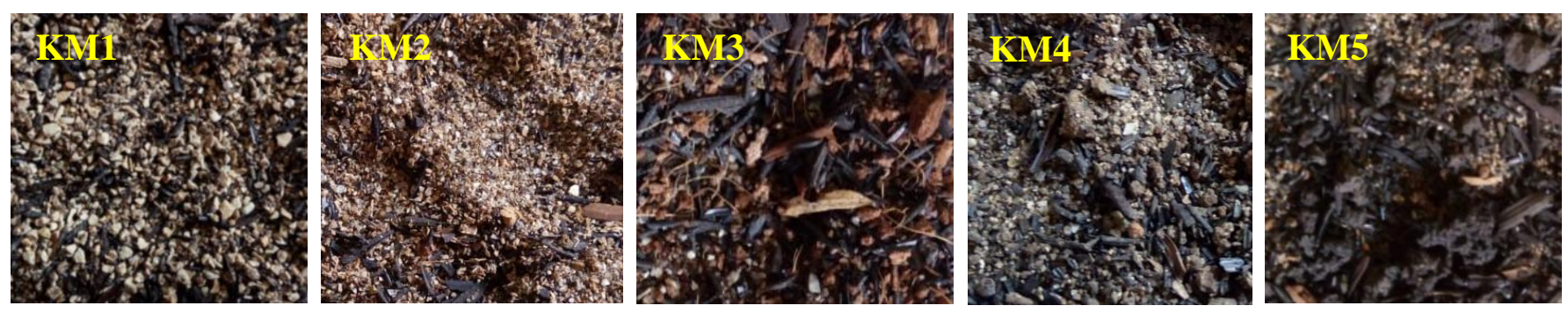

Fig. 1: Physical forms of organic culture media combination for propagation of AM Gigaspora sp. Indigenous, Sorowako. (KM1) Rice husk charcoal, sand, zeolite; (KM2) rice husk charcoal, sand, sawdust; (KM3) rice husk charcoal, sand, cocopeat; (KM4)rice husk charcoal, sand, paddy soil; (KM5) rice husk charcoal, sand, cold magma 


\section{Results}

Analysis of variance showed that treatment of organic culture media combination had a significant effect on the number and diameter of spores of AM Gigaspora sp., and results of the Duncan test for spore number variables showed that combination media of rice husk charcoal, sand, paddy soil, produced the highest number of spores than the combination of other media (Fig. 2A), whereas, for the spore diameter variable, Duncan's test showed that there was no difference in the combination of rice husk charcoal media, sand, paddy soil, and the combination of rice husk charcoal, sand, and cocopeat (Fig. 2B).

It is suspected that the combination of rice husk charcoal, sand, paddy soil, has a good environmental effect on the life cycle of Gigaspora sp., Based on the analysis of the laboratory's to physical properties of media, it shows that combination of media culture organic used has a texture of sand to loamy sand (Table 1). The sand texture has more macropores and is thought to be in accordance with the development of the spores of Gigaspora sp. which are larger than the spores of Glomus sp. and Acaulospora sp. (Syafruddin et al., 2016). However, media the growth and development of each mycorrhizal spore were not the same.

Spores of AM Gigaspora sp., were the spores with the largest size $(205-600 \mu \mathrm{m})$ than to spores of AM Glomus sp. and Acaulospora sp., formed from the tip of a rounded hypha (bulbous suspensor), then appear small spheres that enlarge to reach the maximum size which eventually become spores (Vieira et al., 2020). The suspension is attached to the outer surface of the spore wall. The characteristic is the presence of a bulbous suspensor without a germination shield (Ismael et al., 2020). Gigaspora found in the culture media of rice husk charcoal, sand, cocopeat, and culture media of rice husk charcoal, sand, paddy soil has a diameter of $>250 \mu \mathrm{m}$, while in other media combinations it is still relatively small. It is assumed that the spores formed have not reached their maximum size and are still experiencing growth.

Spores are an important component as a source of inoculum (Berruti et al., 2016). Gigaspora inoculums are spores (Coelho et al., 2014), while Acaulospora and Glomus inoculums are spores, mycorrhizal roots, and extraradical hyphae (Songachan and Kayang, 2013). Acaulospora species took less time to produce spores than Gigaspora species in the same environment (Wang et al., 2015). Furthermore, Gigaspora species usually form mycelium as their active form and produce fewer spores than Acaulospora species (Dodd et al., 2000; Wang and Jiang, 2015). The difference in the number of AM spores is also caused by the spore size, AM Gigaspora takes a longer time to produce spores because of the larger spore size so that it produces fewer spores than the Acaulospora species in the same environment (Costa et al., 2013; Castillo et al., 2016).

Apart from the physical properties of media, the number of spores also is influenced by the chemical properties of media. Soil chemical properties play an important role in the growth and development of AM spores. CEC value is closely related to the level of fertility of the culture media (Carmo et al., 2016). Culture media with high CEC was able to provide better nutrients than low CEC (Saidi and Djamel, 2011; Yunan et al., 2018), as was the CEC in a combination of rice husk charcoal media, sand, soil (Table 1). Febriani et al. (2017) also showed that the culture media for the growth and development of good MA were soil, sand, and rice husk charcoal with an abundance of 89 spores per $100 \mathrm{~g}$ of media, but this study did not provide information on the mycorrhizal genus used.

The media combination of rice husk charcoal, sand, sawdust, greatly reduced the number of Gigaspora sp spores but not at spore diameter variable, this is presumably because sawdust has a high $\mathrm{P}$ content (Table 1 ). The development of AM is limited by the availability of $\mathrm{P}$ nutrients, to some extent an increase in $\mathrm{P}$ levels can increase $\mathrm{AM}$ colonization, but at higher levels, it has a negative effect (Nouri et al., 2014; Mujica et al., 2016), High $\mathrm{P}$ levels can reduce hyphal growth as well as AM colonization and sporulation (Prasad et al., 2012; Sarah et al., 2016). High levels of $P$ in the media combination can reduce the permeability of cell membranes for carbohydrates, so that the supply of phosphate for AM is disturbed (Balzergue et al., 2013; Beltrano et al., 2013). In addition, there are several other possible factors that cause the 
combination of organic culture media (sawdust and cocopeat) to be ineffective, including the activity of parasitic fungi that can kill plant roots and the effect of increasing temperature on the media due to the decomposition process of organic matter which is a consequence of the content. Still high $\mathrm{C} / \mathrm{N}$. Thus the use of organic materials (sawdust and cocopeat) as a carrier for AM should be made in the form of compost. Compost of Eichhornia crassipes (80\%) with zeolite can be used as mycorrhizal carrier material (Ferry et al., 2013; Setiadi et al., 2019). However, the advantage of using organic media combinations is that they have a lighter weight than other media combinations so that they are easy to transport (Table 1).

Table 1. Physical and chemical properties of the combination of organic culture media for Gigaspora sp., Sorowako.

\begin{tabular}{|c|c|c|c|c|c|c|c|c|c|c|}
\hline \multirow{2}{*}{$\begin{array}{l}\text { Combinatio } \\
\text { n of Media } \\
\text { culture } \\
\text { organic }\end{array}$} & \multicolumn{2}{|c|}{ Physical properties } & \multicolumn{8}{|c|}{ Chemical properties } \\
\hline & Texture & $\begin{array}{l}\text { Weight of } \\
\text { media per } 10 \\
\mathrm{~cm}^{3}(\mathrm{~g})\end{array}$ & $\begin{array}{l}\text { pH } \\
\left(\mathrm{H}_{2} \mathrm{O}\right)\end{array}$ & $\begin{array}{l}\text { CEC } \\
\text { cmol (+) } \\
\text { kg-1 }^{-1}\end{array}$ & $\begin{array}{l}\text { BS } \\
\text { (\%) }\end{array}$ & $\mathbf{C} / \mathbf{N}$ & $\begin{array}{l}\mathrm{N} \\
\text { (\%) }\end{array}$ & $\begin{array}{l}\text { P } \\
\text { (ppm) }\end{array}$ & $\begin{array}{l}\text { K } \\
\text { cmol (+) } \\
\text { kg-1 }^{-1}\end{array}$ & $\begin{array}{l}\text { Mg } \\
\text { cmol (+) } \\
\mathbf{k g}^{-1}\end{array}$ \\
\hline KM.1 & Sand & 9.35 & 6.66 & 7.05 & 73 & 9 & 0.17 & 9.68 & 0.41 & 1.25 \\
\hline KM.2 & Sand & 6.49 & 6.67 & 9.58 & 65 & 10 & 0.21 & 11.28 & 0.41 & 1.36 \\
\hline KM.3 & Sand & 6.85 & 6.34 & 8.89 & 47 & 13 & 0.15 & 8.06 & 0.35 & 1.14 \\
\hline KM.4 & Loamy sang & 9.81 & 6.10 & 12.19 & 36 & 16 & 0.12 & 10.31 & 0.52 & 0.85 \\
\hline KM.5 & Sand & 10.77 & 6.44 & 6.93 & 73 & 8 & 0.18 & 12.25 & 0.48 & 1.47 \\
\hline
\end{tabular}

Keterangan: KM1 (rice husk charcoal, sand, zeolite), KM2 (rice husk charcoal, sand, sawdust), KM3 (rice husk charcoal, sand, cocopeat), KM4 (rice husk charcoal, sand, paddy soil), KM5 (rice husk charcoal, sand, magma cold).

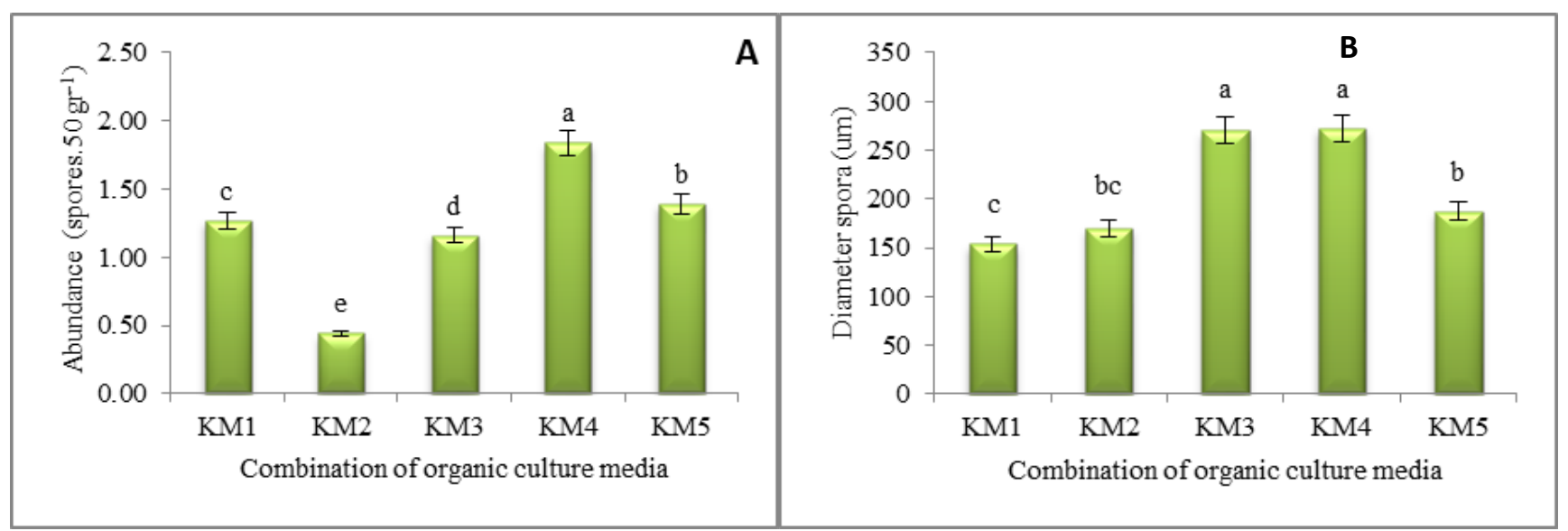

Fig.2: Abundance and diameter of spore AM Gigaspora sp. at combinations of organic culture media. KM1 (rice husk charcoal, sand, zeolite), KM2 (rice husk charcoal, sand, sawdust), KM3 (rice husk charcoal, sand, cocopeat), KM4 (rice husk charcoal, sand, paddy soil), KM5 (rice husk charcoal, sand, magma cold). The spore abundance data shown has

been transformed in logarithmic form.

\section{Discussion}

Zeolite media is good to use as a planting medium because it is stable and does not easily change or be damaged by water spray (Sangeetha and Baskar 2016). Zeolite is a mineral that can improve soil and plant productivity because it is alkaline, so that it can neutralize acidic soils, reduce the power of $P$ fixation by soil colloids, increase CEC, and increase the activity of microorganisms in the soil (Jakkula and Wani, 2018; Kurniawan et al., 2019; Lajszner et al., 2018; Aainaa et al., 2018; Fudlel et al., 2019). Zeolite is a natural mineral that is in form of crystals and has a cavity filled with metal ions and water molecules which can increase the metal ion exchange process that plants need (Wang and Peng, 2010; Mastinu et al., 2019). Spores of AM Acaulospora sp. found in large quantities in zeolite material than sand and latosol soil material (Siregar et al., 2020). Zeolite material is able to 
increase the efficiency of absorption of nutrients, especially $\mathrm{N}$ and $\mathrm{K}$, absorb gas so that it can remove odors, high water absorption so that it can protect roots from dryness, increase ion exchange, especially cations, and release it slowly (slowreleased), and able to maintain moisture aeration carrier material for a long time (Jakkula and Wani, 2018; Zarrintaj et al., 2020). However, the disadvantages of zeolite are the high price of the material and the heavyweight of the material so that it is not effective for mobilization over long distances, as well as the use of wetland soil and cold magma.

Apart from zeolites, AM inoculant propagation can be done on media containing organic matter. Organic matter is part of the soil that comes from plant and animal tissues that have undergone a change in shape and is able to increase the availability of nutrients for plants due to the decomposition process that occurs in the soil, besides that organic matter can increase microbial activity in the soil (Gleixner, 2013; Jacoby et al., 2017; Novak et al., 2019) . Utilization of organic matter as a growing medium for AM inoculants is still rarely used, whereas from several research results it is known that organic matter supports the development of AM propagules (Coelho et al., 2014; Kim et al., 2017).

Cocopeat is an organic growing medium derived from coconut belt powder. Cocopeat has high in chlorine and tannins, which are known to inhibit plant growth (Irawan and Hidayah, 2014). The chlorine content required for cocopeat should not be more than $200 \mathrm{mg} \mathrm{/} \mathrm{L} \mathrm{(Christy,} \mathrm{2020).}$ Therefore, it is very important to soak and wash the cocopeat raw material for several hours to remove excess chlorine and tannins (Irawan and Hidayah, 2014). The advantages of cocopeat as a planting medium include: it has high water absorption, can store water in pores, contains nutrients because it will store liquid fertilizer, reduces the frequency of fertilization, contains very natural nutrients, loosens the soil with a neutral degree of soil acidity, namely 5,8-6, and supports rapid root growth and is therefore good for culture media (Awang et al., 2009; Laure et al., 2017). According to Kalaivani and Jawaharlal (2019), Fazilah et al. (2017), Jain and Sunita, (2016) cocopeat, a planting medium that is able to hold water up to $73 \%$ of the $41 \mathrm{ml}$ water that is flowed through the cocopeat layer. In addition, the cocopeat medium has a lightweight so that it can be used as a carrier for AM inoculum

Rice husks charcoal are organic materials derived from agricultural waste which contain several important elements such as crude protein, fat, crude fiber, carbon, hydrogen, oxygen, and silica (Ahiduzzaman and Islam, 2016; Babosa and Sharanagouda, 2017). Besides being able to be used as a material that improves soil by increasing air permeability and water percolation, rice husk charcoal also has good porosity for root development and has high water-holding power, besides that, rice husk charcoal can be used as a growing medium for microbial inoculants such as mycorrhizae (Milla et al., 2013; Win et al., 2019; Seran, 2018). The use of rice husk as a growing medium for AM inoculants has not been widely used. The use of rice husk and quartz sand with a ratio of 3: 1 as a growing medium for AM inoculant with a corn host plant was able to create suitable conditions for the development of Glomus fasiculatum (Badar and Qureshi, 2014; Koyama et al., 2016; Husna et al., 2019).

Important things to consider in inoculum multiplication are the compatible host plant (Medina and Azcon, 2010), culture media (Coelho et al., 2014), and growth of the environment (Goetten et al., 2016). This is important to consider because AM is obligate, and the needs of each AM for these factors are not always the same (Berruti et al., 2016). Inoculum multiplication must have high infectivity and effectiveness, fast colonization of host roots, and produce a lot of spores (Ijdo et al., 2011). AM does not select a specific host plant, all plants are potentially infected, but the level of infectivity and effectiveness is different for each host association and AM, although AM infects and colonizes the roots of various plant species, there are plant species that the preferred by showing plant root colonization response which maximum (Ohtomo et al., 2018; Chen et al., 2018; Hao et al., 2019). AM Gigaspora sp. works with hyphae that penetrate into the cortex cells of the host plant from one cell to another, bonding and twisting to form strong, and carry out its function of transferring nutrients from the soil to plants and releasing carbon (C) and Phosphor (P) so that it can be utilized by plants which results in an increase in plant biomass, number of spores and 
degree of root infection (Garg and Aggarwal, 2012; Johri et al., 2015; Wipf et al., 2019).

The increase in plant nutrient uptake by AM can be carried out in six ways, namely: (1) increasing of nutrient uptake capacity by root, because mycorrhizal roots live longer (Mohammadi et al., 2011), (2) causing better P movement (Tran et al., 2020), (3) expanding the absorption area, through the area of plant roots (Wang et al., 2017), (4) increase the direct or indirect transfer of nutrients among mycorrhizal plants (Ingraffia et al., 2019), (5) external hyphae expand the absorption area because the diameter is smaller than the plants roots $(1 \mu \mathrm{m})$, thereby increasing nutrient uptake (Zhang et al., 2016), and (6) inducing the formation of organic acids and phosphatases (Wang et al., 2019), and increasing the plant's $P$ supply through leaching and mineralization (Jalali et al., 2014).

\section{Conclusion}

The combination of rice husk charcoal media, sand, cocopeat, and the combination of rice husk charcoal media, sand, paddy soil, resulted in good growth and development of AM Gigaspora spores. The combination of organic culture media can be used as a carrier for AM, a combination of rice husk charcoal, sand, sawdust, and a combination of rice husk charcoal, sand, cocopeat, has the potential to be a carrier for AM Gigaspora sp indigenous Sorowako, because it has a lightweight, but should be used after decomposed to form compost.

\section{Acknowledgments}

The author would like to thank the Ministry of Research, Technology, and Higher Education of the Republic of Indonesia for providing support through the multi-year basic research competition (2019-2021).

\section{References}

Aainaa, H. N., Ahmed, O. H., Majid, N. M. A. 2018. Effects of Clinoptilolite Zeolite on Phosphorus Dynamics and Yield of Zea Mays L. Cultivated on an Acid Soil. PLoS ONE 13 (9): 1-19.

Ahiduzzaman, M., and Islam, A. K. M. S.. 2016. Preparation of Porous Bio-Char and Activated
Carbon from Rice Husk by Leaching Ash and Chemical Activation. SpringerPlus 5 (1).

Akib, M. A. 2019. Prosedur Rancangan Percobaan: Aplication of The Model in Different Environmental Conditions. Lampena Intimedia Press, 2nd ed. Parepare-Indonesia.

Akib, M. A., Mustari, K., Kuswinanti, T., Syaiful, S. A. 2018. Abundance of Arbuscular Mychorrizal Fungi in Rehabilitation Area of Nickel PostMining Land of Sorowako, South Sulawesi. In IOP Conference Series: Earth and Environmental Science. Vol. 157.

Asmelash, F., Bekele, T., Birhane, E. 2016. The Potential Role of Arbuscular Mycorrhizal Fungi in the Restoration of Degraded Lands. Frontiers in Microbiology 7 (JUL): 1-15.

Awang, Y., Shaharom, A. S., Mohamad, R. B., Selamat, A. 2009. Chemical and Physical Characteristics of Cocopeat-Based Media Mixtures and Their Effects on the Growth and Development of Celosia Cristata. American Journal of Agricultural and Biological Science 4 (1): $63-71$

Babaso, P. N., H. Sharanagouda, H. 2017. Rice Husk and Its Applications: Review. International Journal of Current Microbiology and Applied Sciences 6 (10): 1144-56.

Badar, R., Qureshi, S. A. 2014. Composted Rice Husk Improves the Growth and Biochemical Parameters of Sunflower Plants. Hindawi Publishing Corporation, Journal of Botany (2014), Article ID 427648, 6 p.

Balzergue, C., Chabaud, M., Barker, D. G., Becard, G., Rochange, S. F. 2013. High Phosphate Reduces Host Ability to Develop Arbuscular Mycorrhizal Symbiosis without Affecting Root Calcium Spiking Responses to the Fungus. Frontiers in Plant Science 4 (OCT): 1-15.

Begum, N., Qin, C., Ahanger, M. A., Raza, S., Khan, M. I., Ashraf, M., Ahmed, N., Zhang, L. 2019. Role of Arbuscular Mycorrhizal Fungi in Plant Growth Regulation: Implications in Abiotic Stress Tolerance. Frontiers in Plant Science 10 (September): 1-15.

Beltrano, J., Ruscitti, M., Arango, M. C., Ronco, M. 2013. Effects of Arbuscular Mycorrhiza Inoculation on Plant Growth, Biological and Physiological Parameters and Mineral Nutrition in Pepper Grown under Different Salinity and p Levels. Journal of Soil Science and Plant Nutrition 13 (1): 123-41.

Bender, S. F., Plantenga, F., Neftel, A., Jocher, M., 
Oberholzer, H. R., Kohl, L., Giles, M., Daniell, T. J., Heijden, M. G. A. V. D. 2014. Symbiotic Relationships between Soil Fungi and Plants Reduce N2O Emissions from Soil. ISME Journal 8 (6): 1336-45.

Berruti, A., Lumini, E., Balestrini, R., Bianciotto, V. 2016. Arbuscular Mycorrhizal Fungi as Natural Biofertilizers: Let's Benefit from Past Successes. Front. Microbiol. 6: 1559

Carmo, D. L., Lima, L. B., Silva, C. A. 2016. Soil Fertility and Electrical Conductivity Affected by Organic Waste Rates and Nutrient Inputs Davi Lopes. Revista Brasileira de Ciencia Do Solo 40: $1-17 .$.

Castillo, C. G., Borie, F., Oehl, F., Sieverding, E. 2016. Arbuscular Mycorrhizal Fungi Biodiversity: Prospecting in Southern-Central Zone of Chile. A Review. Journal of Soil Science and Plant Nutrition 16 (2): 400-422.

Cely, M. V. T., Oliveira, A. G., Freitas, V. F., Luca, M. B., Barazetti, A. R., Santos, I. M. O., Gionco, B., Garcia, G. V., Prete, C. E. C., Andrade, G. 2016. Inoculant of Arbuscular Mycorrhizal Fungi (Rhizophagus Clarus) Increase Yield of Soybean and Cotton under Field Conditions. Frontiers in Microbiology 7 (May): 1-9.

Chen, H., Yang, X., Wang, P., Wang, Z., Li, M., Zhao, F. J. 2018. Dietary Cadmium Intake from Rice and Vegetables and Potential Health Risk: A Case Study in Xiangtan, Southern China. Science of the Total Environment, 639: 271277.

Christy, J. 2020. Increace of Melon (Cucumic Melo L.) Plant Fruit Production Hydroponically. Agrium, 22(3): 150-56.

Coelho, I. R., Maria, V. L., Bonfim, P., Silva, F. S. B., Maia, L. C. 2014. Optimization of the Production of Mycorrhizal Inoculum on Substrate with Organic Fertilizer. Brazilian Journal of Microbiology 45 (4): 1173-78

Costa, A. F., Haddad, L. S. A. M., Kasuya, M. C. M., Oton, W. C., Costa, M. D., Borges, A. C. 2013. Cultura in Vitro de Gigaspora Decipiens e Glomus Clarum Em Raízes Transformadas de Cenoura: Influência Da Temperatura e PH. Acta Scientiarum - Agronomy 35 (3): 315-23.

Dodd, C. J., Boddington, C. L., Rodriguez, A., Carmen, G., Mansur, I. 2000. Mycelium of Arbuscular Mycorrhizal Fungi (AMF) from Different Genera: Form, Function and Detection. Plant and Soil 226: 131-51.

Fazilah, W., Ilahi, F., Ahmad, D. 2017. A Study on the Physical and Hydraulic Characteristics of Cocopeat Perlite Mixture as a Growing Media in Containerized Plant Production. Sains Malaysiana 46 (6): 975-80

Febriani, W., Riniarti, M., Surnayanti. 2017. The Aplication of Various Planting Media and Spore Inoculums to Improve Ectomycorrhizal Colonization and Growth of Shorea Javanica. Jurnal Sylva Lestari 5 (3): 87-94.

Ferry, Y., Towaha, J., Sasmita, R. R. K. D. 2013. Plant Water Compost Usage as a Carrier of Mycorrhizal Inoculant from Bushy Pepper Cultivation in the Post-Tin Mining Soil Provinsi Kepul. Jurnal Littri 19 (1): 15-22.

Fudlel, A. Y., Minardi, S., Hartati, S., Syamsiyah, J. 2019. Studying the Residual Effect of Zeolite and Manure on Alfisols. Journal of Soil Science and Agroclimatology, 16(2): 181-190.

Garg, N., Aggarwal, N. 2012. Effect of Mycorrhizal Inoculations on Heavy Metal Uptake and Stress Alleviation of Cajanus Cajan (L.) Millsp. Genotypes Grown in Cadmium and Lead Contaminated Soils. Plant Growth Regulation 66 (1): 9-26.

Gleixner, G. 2013. Soil Organic Matter Dynamics: A Biological Perspective Derived from the Use of Compound-Specific Isotopes Studies. Ecological Research 28 (5): 683-95. https://doi.org/10.1007/s11284-012-1022-9.

Goetten, L. C., Moretto, G., Sturmer, S. L. 2016. Influence of Arbuscular Mycorrhizal Fungi Inoculum Produced On-Farm and Phosphorus on Growth and Nutrition of Native Woody Plant Species from Brazil. Acta Botanica Brasilica 30 (1): 9-16.

Hao, Z., Xie, W., Chen, B. 2019. Arbuscular Mycorrhizal Symbiosis Affects Plant Immunity to Viral Infection and Accumulation. Viruses 11 (6): 1-12.

Husna, N., Budianta, D., Munandar., Napoleon, A. 2019. Evaluation of Several Biochar Types as Inoculant Carrier for Indigenous Phosphate Solubilizing Microoorganism from Acid Sulphate Soil. Journal of Ecological Engineering 20 (6): 1-8.

Ijdo, M., Cranenbrouck, S., Declerck, D. 2011. Methods for Large-Scale Production of AM Fungi: Past, Present, and Future. Mycorrhiza. 21 (1): 1-16.

Ingraffia, R., Amato, G., Frenda, A. S., Giambalvo, D. 2019. Impacts of Arbuscular Mycorrhizal Fungi on Nutrient Uptake, N 2 Fixation, N 
Transfer, and Growth in a Wheat/Faba Bean Intercropping System. PLoS ONE 14 (3): 1-16

Irawan, A., Hidayah, N. 2014. Suitability of Cocopeat as a Transdplanting Media in The Polytube of Magnolia Elegans ( Blume .) $\mathrm{H}$. Keng Seedlings. Jurnal Wasian 1 (2): 73-76.

Ismael, H. R., Honore, I. K., Abaka, A. S., Philippe, K., Clautilde, M. 2020. Diversity of Arbuscular Mycorrhizal Fungi (AMF) Associated with Cotton (Gossypium Hirsutum L.) Growing in the Far-North Region of Cameroon. African Journal of Microbiology Research 14 (6): 21124.

Jacoby, R., Peukert, M., Succurro, A., Koprivova, A., Kopriva, S. 2017. The Role of Soil Microorganisms in Plant Mineral NutritionCurrent Knowledge and Future Directions. Frontiers in Plant Science 8 (September): 1-19

Jain, S., Sunita, C. 2016. A Screening Tool for Quality of Mycorrhizal Bio FertilizerMycorrhiza Inoculum Potential. Int. J. of Life Sciences. Special Issue, A7: 81-84.

Jakkula, V. S., Wani, S. P. 2018. Zeolites: Potential Soil Amendments for Improving Nutrient and Water Use Efficiency and Agriculture Productivity. Sci Revs Chem Commun. 8 (1): 119.

Jalali, M., Mahdavi, S., Ranjbar, F. 2014. Nitrogen, Phosphorus and Sulfur Mineralization as Affected by Soil Depth in Rangeland Ecosystems. Environmental Earth Sciences, 72 (6): $1775-88$.

Johri, A. K., Oelmüller, R., Dua, M., Yadav, V., Kumar, M., Tuteja, N., Varma, A., Bonfante, P., Persson, B. L., Stroud, R. M. 2015. Fungal Association and Utilization of Phosphate by Plants: Success, Limitations, and Future Prospects. Frontiers in Microbiology, 6 (OCT): 1-13.

Kalaivani, K., Jawaharlal, M. 2019. Study on Physical Characterization of Coco Peat with Different Proportions of Organic Amendments for Soilless Cultivation. Journal of Pharmacognosy and Phytochemistry 8 (3): 2747-49.

Kim, S. J., Eo, J. K., Lee, E. H., Park, H., Eom, A. H. 2017. Effects of Arbuscular Mycorrhizal Fungi and Soil Conditions on Crop Plant Growth. Mycobiology 45 (1): 20-24.

Kokkoris, V., Hart, M. 2019. In Vitro Propagation of Arbuscular Mycorrhizal Fungi May Drive Fungal Evolution. Frontiers in Microbiology 10
(Oct). https://doi.org/10.3389/fmicb.2019. 02420.

Koyama, S., Katagiri, T., Minamikawa, K., Kato, M., Hayashi, H. 2016. Effects of Rice Husk Charcoal Application on Rice Yield, Methane Emission, and Soil Carbon Sequestration in Andosol Paddy Soil. Japan Agricultural Research Quarterly 50 (4): 319-27.

Lajszner, B. E., Wyszkowska, J., Kucharski, J. 2018. Use of Zeolite to Neutralise Nickel in a Soil Environment. Environmental Monitoring and Assessment 190 (1).

Laure, A. C., Mahindra, C., Ruggoo, A. 2017. Application of Used Hydroponic Substrate as Soil Amendment for Crop Production. Scholars Journal of Agriculture and Veterinary Sciences 4 (8): 311-19.

Malusa, E., Paszt, L. S., Ciesielska, J. 2012. Technologies for Beneficial Microorganisms Inocula Used as Biofertilizers. The Scientific World Journal 2012.

Mastinu, A., Kumar, A., Maccarinelli, G., Bonini, S. A., Premoli, M., Aria, F., Gianoncelli, A., Memo, M. 2019. Zeolite Clinoptilolite: Therapeutic Virtues of an Ancient Mineral. Molecules 24 (8).

Medina, A., Azcon, R. 2010. Effectiveness of the Application of Arbuscular Mycorrhiza Fungi and Organic Amendments to Improve Soil Quality and Plant Performance under Stress Conditions. Journal of Soil Science and Plant Nutrition 10 (3): 354-72.

Milla, O. V., Rivera, E. B., Huang, W. J., Chien, C. C., Wang, Y. M. 2013. Agronomic Properties and Characterization of Rice Husk and Wood Biochars and Their Effect on the Growth of Water Spinach in a Field Test. Journal of Soil Science and Plant Nutrition 13 (2): 251-66.

Mohammadi, K., Khalesro, S., Sohrabi, Y., Heidari, G. 2011. A Review: Beneficial Effects of the Mycorrhizal Fungi for Plant Growth. Journal of Applied Environmental and Biological Sciences 1 (9): 310-19.

Mujica, M. I., Saez, N., Cisternas, M., Manzano, M., Armesto, J. J., Perez, F. 2016. Relationship between Soil Nutrients and Mycorrhizal Associations of Two Bipinnula Species (Orchidaceae) from Central Chile. Annals of Botany 118 (1): 149-58.

Mukhongo, R. W., Tumuhairwe, J. B., Ebanyat, P., Gadir, A. H. A., Thuita, M., Masso, C. 2016. Production and Use of Arbuscular Mycorrhizal 
Fungi Inoculum in Sub-Saharan Africa: Challenges and Ways of Improving. International Journal of Soil Science 11 (3): 108-22.

Nouri, E. , Sessoms, F. B., Feller, U., Reinhardt, D. 2014. Phosphorus and Nitrogen Regulate Arbuscular Mycorrhizal Symbiosis in Petunia Hybrida. PLoS ONE 9 (3).

Novak, E., Carvalho, L. A., Santiago, E. F., Tomazi, M. 2019. Changes in the Soil Structure and Organic Matter Dynamics under Different Plant Covers. Cerne 25 (2): 230-39.

Ohtomo, R., Kobae, Y., Morimoto, S., Oka, N. 2018. Infection Unit Density as an Index of Infection Potential of Arbuscular Mycorrhizal Fungi. Microbes and Environments 33 (1): 3439.

Prasad, K., Aggarwal, A., Yadav, K., Tanwar, A. 2012. Impact of Different Levels of Superphosphate Using Arbuscular Mycorrhizal Fungi and Pseudomonas Fluorescens on Chrysanthemum Indicum L. Journal of Soil Science and Plant Nutrition 12 (3): 451-62.

Saidi, D. 2011. Importance and Role of Cation Exchange Capacity on the Physicals Properties of the Cheliff Saline Soils (Algeria). Procedia Engineering 33: 435-49.

Sangeetha, C., Baskar, P. 2016. Zeolite and Its Potential Uses in Agriculture: A Critical Review. Agricultural Reviews 37: 101-8.

Sarah, S., Muhammad Ibrar, M. 2016. Effects of Arbuscular Mycorrhizal Fungi on Spores Density and Root Colonization of Four Hybrids of Sunflower (Helianthus Annuus L.) at Different Rock Phosphate Levels. Sarhad Journal of Agriculture 32 (4): 258-66.

Seran, T. 2018. Effect of Rice Straw and Husk Biochar on Vegetative Growth and Yield Attributes of Oryza Sativa L. International Journal of Crop Science and Technology 4 (2).

Setiadi, A. A., Purwantisari, S. 2019. Viability and Number of Mycorrhizae Product of Ngudi Makmur Farmer Group in Kataan Village Ngadirejo Temanggung. Jurnal Biologi Tropika 2 (2): 80-84.

Siregar, Z. K., Fikrinda, Alvisyahrin, T. 2020. Pengaruh Media Pembawa Dalam Perbanyakan Spora Fungi Mikoriza Arbuskula. Jurnal Mikologi Indonesia 4 (1): 125-33.

Songachan, L. S., Kayang, H. 2013. Diversity of Arbuscular Mycorrhizal Fungi Associated with Flemingia Vestita Benth. Ex Baker. Mycology 4
(2): $85-95$.

Syafruddin., Syakur., Arabia, T. 2016. Propagation techniques of mycorrhizal bio-fertilizer with different types of mycorrhiza inoculant and host plant in entisol Aceh. Int. J. Agric. Res., 11: 69-76.

Tran, C. T. K., Williams, S. J. W., Smernik, R. J., Cavagnaro, T. R. 2020. Effects of Plant Roots and Arbuscular Mycorrhizas on Soil Phosphorus Leaching. Science of the Total Environment 722: 137847.

Vieira, L. C., Silva, D. K. A., Escobar, I. E. C., Silva, J. M., Moura, I. A., Oehl, F., Silva, G. A. 2020. Changes in an Arbuscular Mycorrhizal Fungi Community along an Environmental Gradient. Plants 9 (1): 1-16.

Walker, C., Mize, C. W., McNabb, H. S. 1982. Populations of Endogonaceous Fungi at Two Locations in Central Iowa. Canadian Journal of Botany 60 (12): 2518-29

Wang, M., Jiang, P. 2015. Colonization and Diversity of AM Fungi by Morphological Analysis on Medicinal Plants in Southeast China. Scientific World Journal 2015. https://doi.org/10.1155/2015/753842.

Wang, P., Wang, T. Y., Wu, S. H., Wen, M. X., Lu, L. M., Ke, F. Z, Wu, Q. S. 2019. Effect of Arbuscular Mycorrhizal Fungi on Rhizosphere Organic Acid Content and Microbial Activity of Trifoliate Orange under Different Low P Conditions. Archives of Agronomy and Soil Science, 65 (14): 2029-42.

Wang, W., Shi, J., Xie, Q., Jiang, Y., Yu, N., Wang, E. 2017. Nutrient Exchange and Regulation in Arbuscular Mycorrhizal Symbiosis. Molecular Plant 10 (9): 1147-58.

Wang. S., Peng, Y. 2010. Natural Zeolites as Effective Adsorbents in Water and Wastewater Treatment. Chemical Engineering Journal 156 (1): 11-24.

Win, K. T., Okazaki, K., Ookawa, T., Yokoyama, T., Ohwaki, Y. 2019. Influence of Rice-Husk Biochar and Bacillus Pumilus Strain TUAT-1 on Yield, Biomass Production, and Nutrient Uptake in Two Forage Rice Genotypes." PLoS ONE 14 (7): 1-21.

Wipf, D., Krajinski, F., Tuinen, D., Ghislaine Recorbet, G., Courty, P. E. 2019. Trading on the Arbuscular Mycorrhiza Market: From Arbuscules to Common Mycorrhizal Networks. New Phytologist 223 (3): 1127-42.

Yunan, D., Xianliang, Q., Xiaochen, W. 2018. Study 
on Cation Exchange Capacity of Agricultural Soils. IOP Conference Series: Materials Science and Engineering 392 (4).

Zarrintaj, P., Mahmodi, G., Manouchehri, S., Mashhadzadeh, A. H., Khodadadi, M., Servatan, M., Ganjali, M. R., Azambre, B., Kim, S. J., Ramsey, J. D., Habibzadeh, S., Saeb, M. R., Mozafari, M.. 2020. Zeolite in
Tissue Engineering: Opportunities and Challenges. MedComm 1 (1): 5-34.

Zhang, H., Liu, Z., Chen, H., Tang, M. 2016. Symbiosis of Arbuscular Mycorrhizal Fungi and Robinia Pseudoacacia L. Improves Root Tensile Strength and Soil Aggregate Stability. PLoS ONE 11 (4): 5-9.

\section{How to cite this article:}

Akib, M. A., Nuddin, A., Prayudyaningsih, R., 2020. Effectiveness of organic culture media combination on propagation of Gigaspora sp. indigenous to Sorowako, Indonesia. Int. J. Curr. Res. Biosci. Plant Biol. 7(9), 10-19. doi: https://doi.org/10.20546/ijcrbp.2020.709.002 